\title{
A Preliminary Evaluation of the Performance of Wind Tunnel and Numerical Modeling Simulations of the Wind Flow Over a Wind Farm
}

\author{
J. C. Barnard \\ H. L. Wegley
}

January 1987

Prepared for the U.S. Department of Energy under Contract DE-AC06-76RLO 1830

Pacific Northwest Laboratory Operated for the U.S. Department of Energy by Battelle Memorial Institute 


\title{
DISCLAIMER
}

This report was prepared as an account of work sponsored by an agency of the United States Government. Neither the United States Government nor any agency thereof, nor Battelle Memorial Institute, nor any of their employees, makes any warranty, expressed or implied, or assumes any legal liability or responsibility for the accuracy, completeness, or usefulness of any information, apparatus, product, or process disclosed, or represents that its use would not infringe privately owned rights. Reference herein to any specific commercial product, process, or service by trade name, trademark, manufacturer, or othenwise, does not necessarily constitute or imply its endorsement, recommendation, or favoring by the United States Government of any agency thereof, or Battelle Memorial Institute. The views and opinions of authors expressed herein do not necessarly state or reflect those of the United States Government or any agency thereof, or Battelle Memorial Institute.

\author{
PACIFIC NORTHWEST LABORATORY \\ operated by \\ BATTELLE \\ for the \\ UNITED STATES DEPARTMENT OF ENERGY \\ under Contract DE-ACO6-76RLO 1830
}

\begin{tabular}{|c|c|}
\hline \multicolumn{2}{|c|}{$\begin{array}{l}\text { Printed in the United States of America } \\
\text { Available from } \\
\text { National Technical Information Service } \\
\text { United States Department of Commerce } \\
5285 \text { Port Royal Road } \\
\text { Springfield, Virginia } 22161\end{array}$} \\
\hline \multicolumn{2}{|c|}{$\begin{array}{l}\text { NTIS Price Codes } \\
\text { Microfiche A01 }\end{array}$} \\
\hline \multicolumn{2}{|c|}{ Printed Copy } \\
\hline Pages & $\begin{array}{l}\text { Price } \\
\text { Codes }\end{array}$ \\
\hline $001-025$ & A02 \\
\hline $026-050$ & $A 03$ \\
\hline $051-075$ & $\mathrm{~A} 04$ \\
\hline $076-100$ & A05 \\
\hline $101-125$ & $A 06$ \\
\hline $126-150$ & $\mathrm{~A} 07$ \\
\hline $151-175$ & AOB \\
\hline $176-200$ & $A 09$ \\
\hline $201-225$ & A010 \\
\hline $226-250$ & A011 \\
\hline $251-275$ & A012 \\
\hline $276-300$ & A013 \\
\hline
\end{tabular}


PNL-6105

UC-60

A PRELIMINARY EVALUATION OF THE PERFORMANCE OF WIND TUNNEL AND NUMERICAL MODELING SIMULATIONS OF THE WIND FLOW OVER A WIND FARM

J. C. Barnard

H. L. Wegley

January 1987

Prepared for the

U.S. Department of Energy

under Contract DE-AC06-76RLO 1830

Pacific Northwest Laboratory

Richland, Washington 99352 
,

.

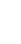




\section{SUMMARY}

This report is an analysis of physical and numerical model simulations of the wind flow over complex terrain. The specific area to which these models were applied is a wind farm in the Altamont Pass area of California. The physical model results were obtained from wind tunnel flow simulations, and the numerical model used was the optimizing version of the NOABL model. The goals of this analysis were 1 ) to evaluate the relative performance of the two models and 2) to uncover any clues that would point toward improvement of the wind tunnel modeling. The performances of the models were gauged by comparing model simulations to wind observations taken over the modeled area.

Unfortunately, the wind observations were too limited to permit us to make an authoritative statement about the relative performance of the two modeling techniques. However, the available evidence indicates that the numerical model performs somewhat better than the physical model. Much more research is necessary to confirm this assertion.

The wind tunnel results were classed as good, intermediate, and poor, based on how well the wind tunnel simulations matched the wind observations. When the tunnel results were compared to the numerical model results, it was found that for the poor tunnel cases, the numerical model predicted a much more southerly (or southeasterly) mean flow direction than was assumed for the tunnel simulations. Therefore, it was conjectured that tunnel simulations using a more southerly flow should improve these poor results. The validity of this hypothesis was demonstrated by the improved match between the tunnel wind speeds and observations for the most southerly tunnel direction when the available tunnel data for three directions were used. 


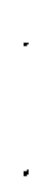




\section{CONTENTS}

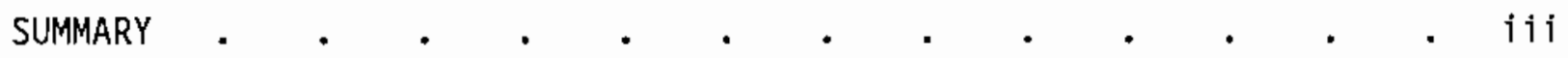

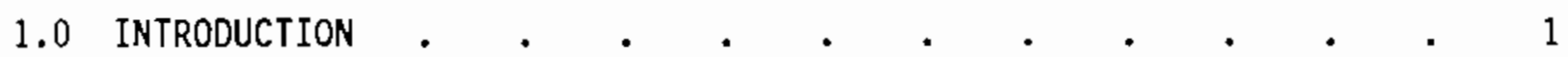

2.0 DESCRIPTION OF THE MODELED AREA AND THE WIND OBSERVATIONS . $\quad 3$

3.0 EVALUATING THE RELATIVE PERFORMANCE OF THE WIND TUNNEL AND

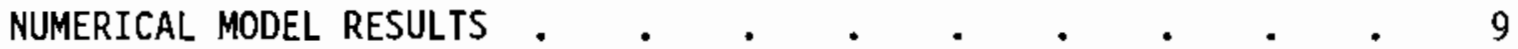

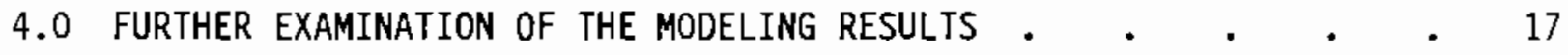

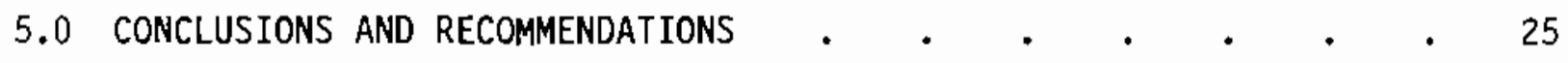

5.0 REFERENCES $\quad . \quad$. $\quad . \quad$. . . . . . . . . . . . . . 27 


\section{FIGURES}

Contour Map of a Wind Farm in the Altamont Pass Area of California.

Scatterplot of the Tunnel RMSE Versus the NOABL Verification RMSE (Deterioration Factor $=1.5$ )

Scatterplot of the Tunnel RMSE Versus the NOABL Verification RMSE (Deterioration Factor $=3.0$ )

The Stability Parameter, $r$, as Calculated by the NOABL Model, Plotted Against Time of Day . . . . .

The Mean Flow Direction, $\theta_{0}$, as Calculated by the NOABL Model, Plotted Against the Reference Wind Direction, $\theta_{r}$.

The Reference Wind Direction Plotted Against the Wind Tunnel RMSE

\section{TABLES}

Twenty-Seven Sets of Hourly Averaged Observed Wind Speed Ratios and Simulated Wind Speed Ratios Obtained From

Wind-Tunnel Ratios for Three Assumed Wind Directions

RMSEs Calculated for the Wind Tunnel and the NOABL Model

Mean Flow Direction, $\theta_{0}$, and Stability Parameter, $\tau$, as Calculated by the NOABL Mode1 for the 27 Cases..

Average Reference Direction of the Worst, Intermediate, and Best Tunnel Cases . . . . . . . 


\subsection{INTRODUCTION}

Wind farm developers have found that wind speeds can vary considerably over wind farms located in complex terrain. Because of this, they need techniques that can simulate the wind flow in complex terrain. These techniques can be used during the design of a wind farm so that turbines are not sited in areas of low wind speeds. Numerical modeling and physical modeling (i.e., wind tunnet flow simulations) are two techniques that have been considered for this purpose and, in the past few years, research has been performed to assess the usefulness of each of these techniques to wind turbine siting (Hiester and Pennell 1981).

One important aspect of research that has been neglected so far is a relative evaluation of the performances of the two modeling techniques. Such an evaluation is the main goal of this report and is done by comparing the results of wind flow simulations made by both modeling techniques to wind observations taken within the modeled area. Regrettably, the wind data set used in this study includes too few wind observation sites to permit a conclusive comparison of the two modeling techniques; nevertheless, a useful and interesting analysis is still possible.

Another goal of this report is to seek reasons for poor matches between the wind tunnel flow simulations and the wind observations. This is accomplished by a more detailed investigation of the modeling results. Specifically, parameters that describe the stability and the direction of the mean flow, as calculated by the numerical model, are examined to uncover any connection between poor tunnel results and particular values of these parameters.

The area to which the physical and numerical models were applied is a wind farm located in the Altamont Pass area of California. Over this farm, wind observations were made at eight stations, and at these stations wind speed ratios derived from wind tunnel flow simulations are available. The numerical modeling results were obtained by applying the optimizing version of the NOABL model (Barnard et aT. 1985) to a section of the wind farm. (Henceforth, this version of the NOABL model will be referred to as the NOABL model.) This 
model is an improved mass-consistent model, which requires wind observations within the modeled area as input. The model then calculates a threedimensional wind field that conserves mass throughout the modeled area. This calculated field can be used to estimate the winds at places removed from the wind observation sites. 


\subsection{DESCRIPTION OF THE MODELED AREA AND THE WIND OBSERVATIONS}

Measurements of the wind speed were taken at eight sites as part of a wind resource assessment for the wind farm development. Figure 1 is a contour map that depicts the terrain of the wind farm and the location of the wind observation sites, which are indicated by the black dots. The number next to each dot is its station identifier. The wind direction was only measured at one of the eight stations, 403 .

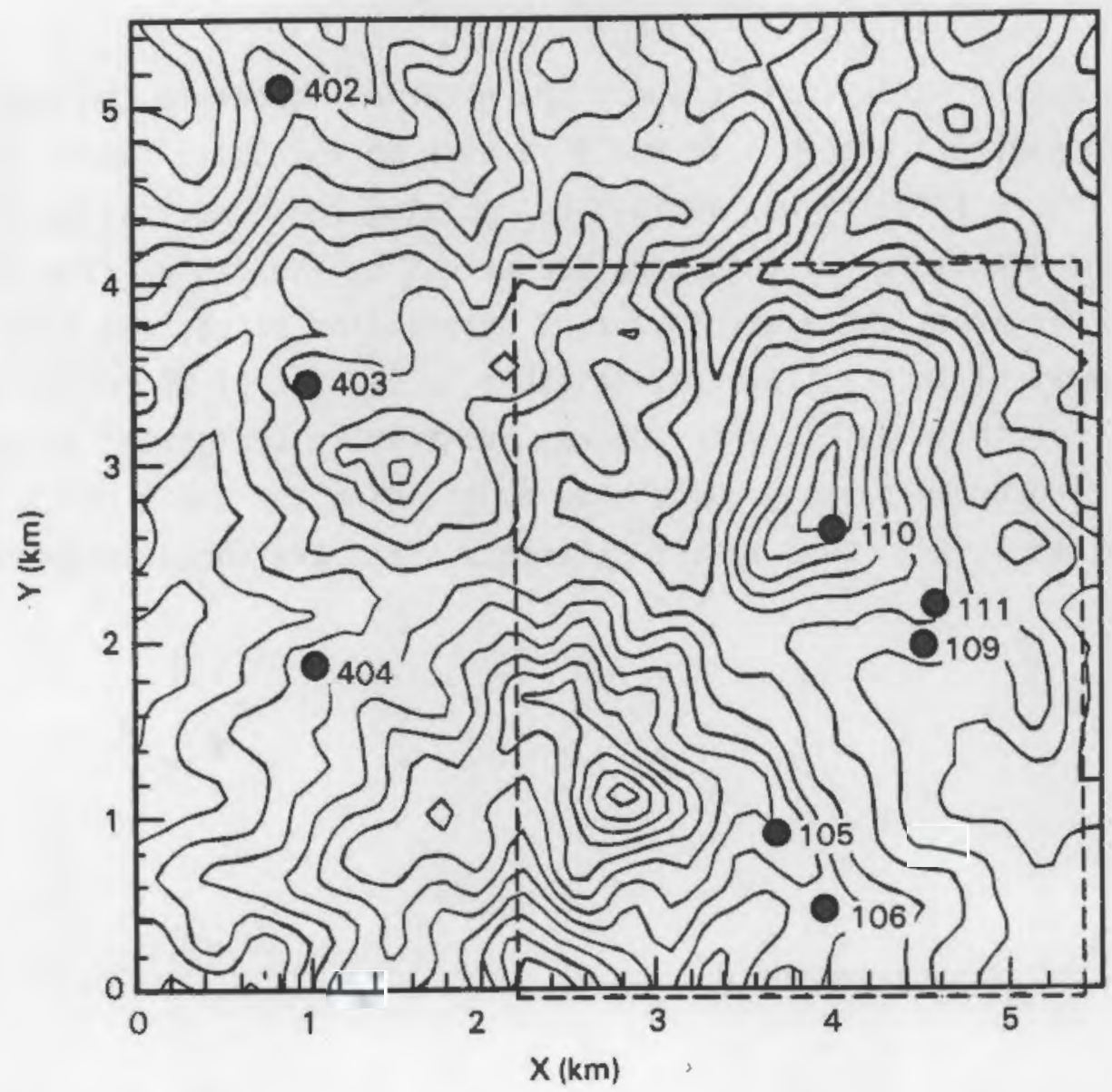

Contour Interval - $20 \mathrm{~m}$

FIGURE 1. Contour Map of a Wind Farm in the Altamont Pass Area of California. The locations of wind observation sites are indicated by the black dots. The NOABL model was applied to the area enclosed by the dashed line. Wind tunnel ratios are available for all B sites. 
From measurements made at these sites, 27 cases of hourly averaged wind speeds were selected for use in this study. These cases represented a variety of wind tunnel performance levels, where the performance is measured by the goodness of fit between the tunnel winds and the wind observations. We chose observation data that spanned the range of tunnel performance for two reasons. The first of these is that these data presumably represent a wide range of meteorological conditions, and it is desirable to determine how well both models perform in different meteorological situations. Second, comparisons of the poor tunnel results to numerical modeling results could provide clues as to why the poor tunnel results occurred. These clues could then lead to improvements in the wind tunnel applications.

It was not practical to apply the numerical model to the entire area shown in Figure 1, because it would require an excessive amount of computer time. This difficulty was avoided by applying the numerical model to a smaller area; the boundaries of this area are marked by the dashed lines in Figure 1. Within this area, there are five wind observation sites, and wind speeds for all or most of these sites are available in the set of 27 hourly averaged cases. For these cases, site 105 was arbitrarily designated as the 'reference' site. Wind speed ratios, calculated by dividing the speed observed at the other sites by the speed at the reference site, are shown in column 3 of Table 1. 
TABLE 1. Twenty-Seven Sets of Hourly Averaged Observed wind Speed Ratios and Simulated Wind Speed Ratios Obtained From Either the Wind Tunnel or the NOABL Model

\begin{tabular}{|c|c|c|c|c|c|c|}
\hline Case & Site & $\begin{array}{c}\text { Observed } \\
\text { Wind Speed } \\
\text { Ratios } \\
\end{array}$ & $\begin{array}{l}\text { Reference } \\
\text { Wind } \\
\text { Direction, } \\
\text { (Site 403) } \\
\end{array}$ & $\begin{array}{l}\text { Wind Tunnet } \\
\text { Wind } \\
\text { Direction, }\end{array}$ & $\begin{array}{r}\text { Wind } \\
\text { Tunnel } \\
\text { Ratios } \\
\end{array}$ & $\begin{array}{l}\text { NOABL } \\
\text { Model } \\
\text { Ratios } \\
\end{array}$ \\
\hline 18 & $\begin{array}{l}105 \\
106 \\
109 \\
110\end{array}$ & $\begin{array}{l}1.00 \\
0.73 \\
0.70 \\
0.86\end{array}$ & 214 & 210 & $\begin{array}{l}1.00 \\
0.77 \\
0.66 \\
0.82\end{array}$ & $\begin{array}{l}1.00 \\
0.77 \\
0.67 \\
0.89\end{array}$ \\
\hline $2 B$ & $\begin{array}{l}105 \\
106 \\
109 \\
110 \\
111\end{array}$ & $\begin{array}{l}1.00 \\
0.82 \\
0.65 \\
0.92 \\
0.54\end{array}$ & 224 & 225 & $\begin{array}{l}1.00 \\
0.77 \\
0.51 \\
0.79 \\
0.56\end{array}$ & $\begin{array}{l}1.00 \\
0.87 \\
0.60 \\
0.91 \\
0.73\end{array}$ \\
\hline 3 & $\begin{array}{l}105 \\
106 \\
109 \\
110 \\
111\end{array}$ & $\begin{array}{l}1.00 \\
0.81 \\
0.73 \\
1.01 \\
0.63\end{array}$ & 220 & 225 & $\begin{array}{l}1.00 \\
0.77 \\
0.51 \\
0.79 \\
0.56\end{array}$ & $\begin{array}{l}1.00 \\
0.86 \\
0.68 \\
0.97 \\
0.77\end{array}$ \\
\hline 4 & $\begin{array}{l}105 \\
106 \\
109 \\
110 \\
111\end{array}$ & $\begin{array}{l}1.00 \\
0.90 \\
0.85 \\
1.04 \\
0.90\end{array}$ & 208 & 210 & $\begin{array}{l}1.00 \\
0.77 \\
0.66 \\
0.82 \\
0.65\end{array}$ & $\begin{array}{l}1.00 \\
0.88 \\
0.86 \\
1.03 \\
0.90\end{array}$ \\
\hline 5 & $\begin{array}{l}105 \\
106 \\
109 \\
110\end{array}$ & $\begin{array}{l}1.00 \\
0.70 \\
0.82 \\
1.04\end{array}$ & 210 & 210 & $\begin{array}{l}1.00 \\
0.77 \\
0.66 \\
0.82\end{array}$ & $\begin{array}{l}1.00 \\
0.80 \\
0.76 \\
1.04\end{array}$ \\
\hline $6 \mathrm{~W}$ & $\begin{array}{l}105 \\
106 \\
109 \\
110\end{array}$ & $\begin{array}{l}1.00 \\
0.84 \\
1.03 \\
1.21\end{array}$ & 207 & 210 & $\begin{array}{l}1.00 \\
0.77 \\
0.66 \\
0.82\end{array}$ & $\begin{array}{l}1.00 \\
0.95 \\
0.96 \\
1.21\end{array}$ \\
\hline $7 W$ & $\begin{array}{l}105 \\
106 \\
109 \\
110 \\
111\end{array}$ & $\begin{array}{l}1.00 \\
0.83 \\
0.87 \\
1.18 \\
0.77\end{array}$ & 205 & 210 & $\begin{array}{l}1.00 \\
0.77 \\
0.66 \\
0.82 \\
0.65\end{array}$ & $\begin{array}{l}1.00 \\
0.85 \\
0.83 \\
1.16 \\
0.87\end{array}$ \\
\hline 8 & $\begin{array}{l}105 \\
106 \\
109 \\
110\end{array}$ & $\begin{array}{l}1.00 \\
0.64 \\
0.76 \\
1.17\end{array}$ & 207 & 210 & $\begin{array}{l}1.00 \\
0.77 \\
0.66 \\
0.82\end{array}$ & $\begin{array}{l}1.00 \\
0.79 \\
0.72 \\
1.11\end{array}$ \\
\hline
\end{tabular}


TABLE 1 (cont'd.)

\begin{tabular}{|c|c|c|c|c|c|c|}
\hline Case & Site & $\begin{array}{c}\text { Observed } \\
\text { Wind Speed } \\
\text { Ratios } \\
\end{array}$ & $\begin{array}{l}\text { Reference } \\
\text { Wind } \\
\text { Direction, } \\
\text { (Site 403) }\end{array}$ & $\begin{array}{c}\text { Wind Tunnel } \\
\text { Wind } \\
\text { Direction, }\end{array}$ & $\begin{array}{l}\text { Wind } \\
\text { Tunnel } \\
\text { Ratios } \\
\end{array}$ & $\begin{array}{l}\text { NOABL } \\
\text { Model } \\
\text { Ratios } \\
\end{array}$ \\
\hline $9 w$ & $\begin{array}{l}105 \\
106 \\
109 \\
110\end{array}$ & $\begin{array}{l}1.00 \\
0.67 \\
1.04 \\
1.01\end{array}$ & 206 & 210 & $\begin{array}{l}1.00 \\
0.77 \\
0.66 \\
0.82\end{array}$ & $\begin{array}{l}1.00 \\
0.88 \\
0.86 \\
1.04\end{array}$ \\
\hline 10 & $\begin{array}{l}105 \\
106 \\
109 \\
110\end{array}$ & $\begin{array}{l}1.00 \\
0.74 \\
0.92 \\
1.06\end{array}$ & 211 & 210 & $\begin{array}{l}1.00 \\
0.77 \\
0.66 \\
0.82\end{array}$ & $\begin{array}{l}1.00 \\
0.86 \\
0.84 \\
1.07\end{array}$ \\
\hline 11 & $\begin{array}{l}105 \\
106 \\
109 \\
110\end{array}$ & $\begin{array}{l}1.00 \\
0.84 \\
0.73 \\
1.03\end{array}$ & 223 & 225 & $\begin{array}{l}1.00 \\
0.77 \\
0.51 \\
0.79\end{array}$ & $\begin{array}{l}1.00 \\
0.87 \\
0.73 \\
0.99\end{array}$ \\
\hline 12 & $\begin{array}{l}105 \\
106 \\
109 \\
110\end{array}$ & $\begin{array}{l}1.00 \\
0.80 \\
0.77 \\
0.93\end{array}$ & 231 & 225 & $\begin{array}{l}1.00 \\
0.77 \\
0.51 \\
0.79\end{array}$ & $\begin{array}{l}1.00 \\
0.82 \\
0.75 \\
0.84\end{array}$ \\
\hline 13 & $\begin{array}{l}105 \\
106 \\
109 \\
110\end{array}$ & $\begin{array}{l}1.00 \\
0.89 \\
0.82 \\
0.97\end{array}$ & 217 & 210 & $\begin{array}{l}1.00 \\
0.77 \\
0.66 \\
0.82\end{array}$ & $\begin{array}{l}1.00 \\
0.90 \\
0.81 \\
0.97\end{array}$ \\
\hline $14 B$ & $\begin{array}{l}105 \\
106 \\
109 \\
110\end{array}$ & $\begin{array}{l}1.00 \\
0.88 \\
0.74 \\
0.89\end{array}$ & 217 & 210 & $\begin{array}{l}1.00 \\
0.77 \\
0.66 \\
0.82\end{array}$ & $\begin{array}{l}1.00 \\
0.86 \\
0.76 \\
0.92\end{array}$ \\
\hline 15 & $\begin{array}{l}105 \\
106 \\
109 \\
110\end{array}$ & $\begin{array}{l}1.00 \\
0.80 \\
0.74 \\
0.83\end{array}$ & 221 & 225 & $\begin{array}{l}1.00 \\
0.77 \\
0.51 \\
0.79\end{array}$ & $\begin{array}{l}1.00 \\
0.81 \\
0.71 \\
0.90\end{array}$ \\
\hline 16 & $\begin{array}{l}105 \\
106 \\
109 \\
110\end{array}$ & $\begin{array}{l}1.00 \\
0.77 \\
0.79 \\
1.01\end{array}$ & 220 & 225 & $\begin{array}{l}1.00 \\
0.77 \\
0.51 \\
0.79\end{array}$ & $\begin{array}{l}1.00 \\
0.87 \\
0.75 \\
0.97\end{array}$ \\
\hline 17 & $\begin{array}{l}105 \\
106 \\
109 \\
110\end{array}$ & $\begin{array}{l}1.00 \\
0.76 \\
0.67 \\
1.11\end{array}$ & 223 & 225 & $\begin{array}{l}1.00 \\
0.77 \\
0.51 \\
0.79\end{array}$ & $\begin{array}{l}1.00 \\
0.88 \\
0.71 \\
1.01\end{array}$ \\
\hline
\end{tabular}


TABLE 1 (cont'd.)

\begin{tabular}{|c|c|c|c|c|c|c|}
\hline Case & Site & $\begin{array}{c}\text { Observed } \\
\text { Wind Speed } \\
\text { Ratios } \\
\end{array}$ & $\begin{array}{c}\text { Reference } \\
\text { Wind } \\
\text { Direction, } \\
\text { (Site 403) }\end{array}$ & $\begin{array}{l}\text { Wind Tunne] } \\
\text { Wind } \\
\text { Direction, }\end{array}$ & $\begin{array}{l}\text { Wind } \\
\text { Tunne } 1 \\
\text { Ratios }\end{array}$ & $\begin{array}{l}\text { NOABL } \\
\text { Model } \\
\text { Ratios }\end{array}$ \\
\hline $18 \mathrm{~B}$ & $\begin{array}{l}105 \\
106 \\
109 \\
110\end{array}$ & $\begin{array}{l}1.00 \\
0.73 \\
0.68 \\
0.88\end{array}$ & 217 & 210 & $\begin{array}{l}1.00 \\
0.77 \\
0.66 \\
0.82\end{array}$ & $\begin{array}{l}1.00 \\
0.76 \\
0.66 \\
0.90\end{array}$ \\
\hline $19 \mathrm{~W}$ & $\begin{array}{l}105 \\
106 \\
109 \\
110\end{array}$ & $\begin{array}{l}1.00 \\
0.86 \\
1.03 \\
1.19\end{array}$ & 211 & 210 & $\begin{array}{l}1.00 \\
0.77 \\
0.66 \\
0.82\end{array}$ & $\begin{array}{l}1.00 \\
0.97 \\
0.96 \\
1.01\end{array}$ \\
\hline 20 & $\begin{array}{l}105 \\
106 \\
109 \\
110\end{array}$ & $\begin{array}{l}1.00 \\
0.79 \\
0.73 \\
1.05\end{array}$ & 213 & 210 & $\begin{array}{l}1.00 \\
0.77 \\
0.66 \\
0.82\end{array}$ & $\begin{array}{l}1.00 \\
0.79 \\
0.74 \\
1.04\end{array}$ \\
\hline 21 & $\begin{array}{l}105 \\
106 \\
109 \\
110\end{array}$ & $\begin{array}{l}1.00 \\
0.81 \\
0.76 \\
0.95\end{array}$ & 221 & 225 & $\begin{array}{l}1.00 \\
0.77 \\
0.51 \\
0.79\end{array}$ & $\begin{array}{l}1.00 \\
0.85 \\
0.74 \\
0.93\end{array}$ \\
\hline 22 & $\begin{array}{l}105 \\
106 \\
109 \\
110\end{array}$ & $\begin{array}{l}1.00 \\
0.70 \\
0.87 \\
1.01\end{array}$ & 205 & 210 & $\begin{array}{l}1.00 \\
0.77 \\
0.66 \\
0.82\end{array}$ & $\begin{array}{l}1.00 \\
0.83 \\
0.79 \\
1.02\end{array}$ \\
\hline 23 & $\begin{array}{l}105 \\
106 \\
109 \\
110\end{array}$ & $\begin{array}{l}1.00 \\
0.73 \\
0.71 \\
0.95\end{array}$ & 219 & 225 & $\begin{array}{l}1.00 \\
0.77 \\
0.51 \\
0.79\end{array}$ & $\begin{array}{l}1.00 \\
0.77 \\
0.69 \\
0.96\end{array}$ \\
\hline 24 & $\begin{array}{l}105 \\
106 \\
109 \\
110\end{array}$ & $\begin{array}{l}1.00 \\
0.89 \\
0.84 \\
1.03\end{array}$ & 208 & 210 & $\begin{array}{l}1.00 \\
0.77 \\
0.66 \\
0.82\end{array}$ & $\begin{array}{l}1.00 \\
0.88 \\
0.86 \\
1.02\end{array}$ \\
\hline $25 B$ & $\begin{array}{l}105 \\
106 \\
109 \\
110\end{array}$ & $\begin{array}{l}1.00 \\
0.67 \\
0.76 \\
0.97\end{array}$ & 205 & 210 & $\begin{array}{l}1.00 \\
0.77 \\
0.66 \\
0.82\end{array}$ & $\begin{array}{l}1.00 \\
0.78 \\
0.71 \\
0.98\end{array}$ \\
\hline 26 & $\begin{array}{l}105 \\
106 \\
109 \\
110 \\
111\end{array}$ & $\begin{array}{l}1.00 \\
0.76 \\
0.83 \\
1.15 \\
0.67\end{array}$ & 211 & 210 & $\begin{array}{l}1.00 \\
0.77 \\
0.66 \\
0.82 \\
0.65\end{array}$ & $\begin{array}{l}1.00 \\
0.82 \\
0.77 \\
1.13 \\
0.84\end{array}$ \\
\hline
\end{tabular}


TABLE 1 (cont'd.)

\begin{tabular}{|c|c|c|c|c|c|c|}
\hline Case & Site & $\begin{array}{c}\text { Observed } \\
\text { Wind Speed } \\
\text { Ratios } \\
\end{array}$ & $\begin{array}{l}\text { Reference } \\
\text { wind } \\
\text { Direction, } \\
\text { (Site 403) }\end{array}$ & $\begin{array}{c}\text { Wind Tunnel } \\
\text { Wind } \\
\text { Direction, }\end{array}$ & $\begin{array}{l}\text { Wind } \\
\text { Tunnel } \\
\text { Ratios } \\
\end{array}$ & $\begin{array}{l}\text { NOABL } \\
\text { Model } \\
\text { Ratios }\end{array}$ \\
\hline $27 \mathrm{~W}$ & $\begin{array}{l}105 \\
106 \\
109 \\
110 \\
111\end{array}$ & $\begin{array}{l}1.00 \\
0.85 \\
1.03 \\
1.09 \\
0.81\end{array}$ & 205 & 210 & $\begin{array}{l}1.00 \\
0.77 \\
0.66 \\
0.82 \\
0.65\end{array}$ & $\begin{array}{l}1.00 \\
0.91 \\
0.91 \\
1.10 \\
0.92\end{array}$ \\
\hline
\end{tabular}




\subsection{EVALUATING THE RELATIVE PERFORMANCE OF THE WIND TUNNEL AND NUMERICAL MODEL RESULTS}

Evaluating the relative performance of physical and numerical models requires two steps. First, the results derived from each model must be compared to the wind observations. This comparison is made quantitative by establishing a figure of merit that gauges the goodness-of-fit between mode] results and the observations for each case of hourly averaged wind speeds. In this report, the root mean square error (RMSE) is used as the figure of merit. Since both models are compared to the same set of observations, a pair of RMSEs results from one case of wind data. (As will be explained later, the comparison of the numerical model simulations to the observations is compromised by the inadequate number of observation sites.) Second, after the comparison is completed for all cases of data, a graphical and simple statistical analysis is performed on the pairs of RMSEs. This analysis is used to compare the performance of the models.

Wind speed ratios obtained from wind tunnel flow simulations over the wind farm are shown in Table 2. (Like the ratios of the wind observations, these ratios were calculated using site 105 as the reference site. Thus they are the ratio of the speed at each site to the speed at site 105.) The wind tunnel simulations were performed for three specific wind directions $\left(195^{\circ}\right.$, $210^{\circ}$, and $225^{\circ}$ ) that typify the primary directions of the prevailing flow. When comparing the wind tunnel ratios to a specific case of the wind observations, it is necessary to choose wind tunnel ratios corresponding to one of these three directions. This choice was based on an estimate of the direction of the actual flow over the wind farm obtained from the direction measurement at site 403 . The set of wind tunnel ratios whose direction was closest to the measured direction was the set that was compared against the observations. The 403 direction and the selected wind tunnel direction (i.e., either $195^{\circ}$, $210^{\circ}$, or $225^{\circ}$ ) are shown in columns 4 and 5 of Table 1 , respectively. (To facilitate the comparison of the wind tunnel ratios to the other ratios, the wind tunnel ratios that correspond to the selected tunnel direction are listed in column 6 of Table 1.) 

TABLE 2. Wind-Tunnel Ratios for Three Assumed
Wind Directions

\begin{tabular}{|c|c|c|c|}
\hline \multirow[b]{2}{*}{ Site } & \multicolumn{3}{|c|}{ Wind Direction } \\
\hline & $\underline{195^{\circ}}$ & $210^{\circ}$ & $225^{\circ}$ \\
\hline 105 & 1.00 & 1.00 & 1.00 \\
\hline 106 & 0.87 & 0.77 & 0.77 \\
\hline 109 & 0.68 & 0.66 & 0.51 \\
\hline 110 & 0.97 & 0.82 & 0.79 \\
\hline 111 & 0.80 & 0.65 & 0.56 \\
\hline
\end{tabular}

Wind speed ratios were derived by applications of the NOABL model for each of the 27 cases. These ratios are displayed in column 7 of Table 1 . As in the case of the wind observations, the ratios were formed using site 105 as the reference site.

A measure of the 'goodness-of-fit' between the modeled ratio and the observed ratios is the root mean square error (RMSE). This is defined as

$$
\text { RMSE }=\left[\sum_{i=1}^{N}\left(r_{i}^{m}-r_{i}^{0}\right)^{2} / N\right]^{1 / 2}
$$

where $N$ is the number of sites, $r_{i}^{m}$ are the ratios obtained from either of the modeling techniques, and $r_{i}^{0}$ are the observed ratios. For each specific case of wind observation data, two RMSEs are calculated, one for the tunnel results and the other for the NOABL model results. For the 27 cases under consideration, these RMSEs are given in columns 2 and 3 of Table 3.

The RMSEs obtained from comparing the tunnel ratios to the observed ratios, termed as 'tunnel' RMSEs, form a basis of classifying the match between the tunnel and observed winds as either poor, intermediate, or good. Of the 27 cases, the five with the largest RMSEs and the five with the smallest RMSEs are considered to be the worst cases and the best cases, respectively. These are indicated in column 1 of Tables 1,3 , and 4 by a ' $W$ ' or ' $B$ ' appended to the case number. All other cases are termed as 'intermediate' cases. 
TABLE 3. RMSEs Calculated for the Wind Tunnel and the NOABL Model. The RMSE in column 4 is the NOABL RMSE multiplied by a deterioration factor of 1.5 .

\begin{tabular}{|c|c|c|c|}
\hline Case & $\begin{array}{l}\text { Wind } \\
\text { Tunnel } \\
\end{array}$ & $\begin{array}{l}\text { Optimizing } \\
\text { NOABL Model }\end{array}$ & $\begin{array}{l}\text { NOABL } \\
\text { RMSE } \times 1.5 \\
\end{array}$ \\
\hline 1B & 0.036 & 0.030 & 0.045 \\
\hline $2 B$ & 0.090 & 0.093 & 0.140 \\
\hline 3 & 0.142 & 0.070 & 0.105 \\
\hline 4 & 0.180 & 0.011 & 0.017 \\
\hline 5 & 0.139 & 0.057 & 0.086 \\
\hline $6 W$ & 0.271 & 0.065 & 0.098 \\
\hline $7 W$ & 0.196 & 0.052 & 0.078 \\
\hline 8 & 0.193 & 0.083 & 0.125 \\
\hline $9 w$ & 0.217 & 0.137 & 0.206 \\
\hline 10 & 0.177 & 0.072 & 0.108 \\
\hline 11 & 0.166 & 0.025 & 0.038 \\
\hline 12 & 0.148 & 0.015 & 0.023 \\
\hline 13 & 0.125 & 0.007 & 0.011 \\
\hline 148 & 0.077 & 0.021 & 0.032 \\
\hline 15 & 0.119 & 0.038 & 0.057 \\
\hline 16 & 0.180 & 0.057 & 0.086 \\
\hline 17 & 0.177 & 0.079 & 0.119 \\
\hline $18 B$ & 0.039 & 0.018 & 0.027 \\
\hline $19 W$ & 0.267 & 0.112 & 0.168 \\
\hline 20 & 0.119 & 0.007 & 0.011 \\
\hline 21 & 0.147 & 0.023 & 0.035 \\
\hline 22 & 0.145 & 0.075 & 0.113 \\
\hline 23 & 0.129 & 0.024 & 0.036 \\
\hline 24 & 0.150 & 0.013 & 0.020 \\
\hline $25 \mathrm{~B}$ & 0.102 & 0.059 & 0.089 \\
\hline 26 & 0.166 & 0.097 & 0.146 \\
\hline $27 W$ & 0.220 & 0.075 & 0.113 \\
\hline
\end{tabular}


It is important to point out that the RMSEs calculated for the NOABL mode1 give an overly optimistic evaluation of the model's performance, and therefore comparisons between these RMSEs and the tunnel RMSEs would tend to slight the tunnel performance. This occurs because the wind observations are used solely to verify the tunnel simulations, while for the numerical model they are needed by the model for a tuning process. Winds calculated by the NOABL model are highly sensitive to two parameters: $\tau_{1}{ }^{(a)}$ which is used to estimate the atmospheric stability, and $\theta_{0}$, the direction of mean flow. Often appropriate values for these parameters are not known beforehand; however, a tuning process is used with the NOABL model to calculate optimum values for them. In this process, observations from a number of sites, known as 'tuning' sites, are used to tune the mode $1_{\text {; }}$ this tuning adjusts the unknown parameters until the discrepancy between the winds at the tuning sites and the model's calculation of these winds is minimized. Thus, the RMSE between observed and calculated ratios at the tuning sites, called the 'tuning' RMSE, actually measures the model's ability to simulate the winds at places where the winds are already known. The skill of the model in reproducing winds used as input to the model does not reflect the true performance of the madel. A much more appropriate measure of the model's performance is the RMSE between modelderived winds, at places away from the tuning sites, and the actual winds at these locations. When wind observation sites are abundant, one group of sites can be used in model tuning. The remaining sites can be used to verify the model. The error between modeled and actual winds at these sites is known as the verification RMSE, and it is important that tunnel RMSEs are compared to these verification RMSEs, rather than to the tuning RMSEs.

In this study, because of the small number of wind observation sites, all the existing wind observations had to be used for model tuning, and it was not possible to calculate verification RMSEs. However, a past study (Barnard et al. 1985) showed that there is a correlation between tuning and verification RMSEs, so that verification RMSEs can be estimated from the

(a) The $\tau$ used in this report is the logarithm (base 10) of the $\tau$ used by Barnard et al. 1985. 
tuning RMSEs. The data from this study suggest that the verification RMSE is related to the tuning RMSE in a simple manner:

\section{Verification RMSE Tuning RMSE $-f$}

where $f$ is a 'deterioration factor', equal to about 1.5. Using this value for $f$, we estimated NOABL verification RMSEs; these can then be compared to the tunnel RMSEs. These verification RMSEs are shown in column 4 of Table 3 .

One simple way of comparing the tunnel RMSEs to the NOABL verification RMSEs is by using a scatterplot. In Figure 2, the tunnel RMSE is plotted against the estimated NOABL verification RMSE for each of the 27 pairs of RMSEs. If both models perform equally well, the points will cluster about

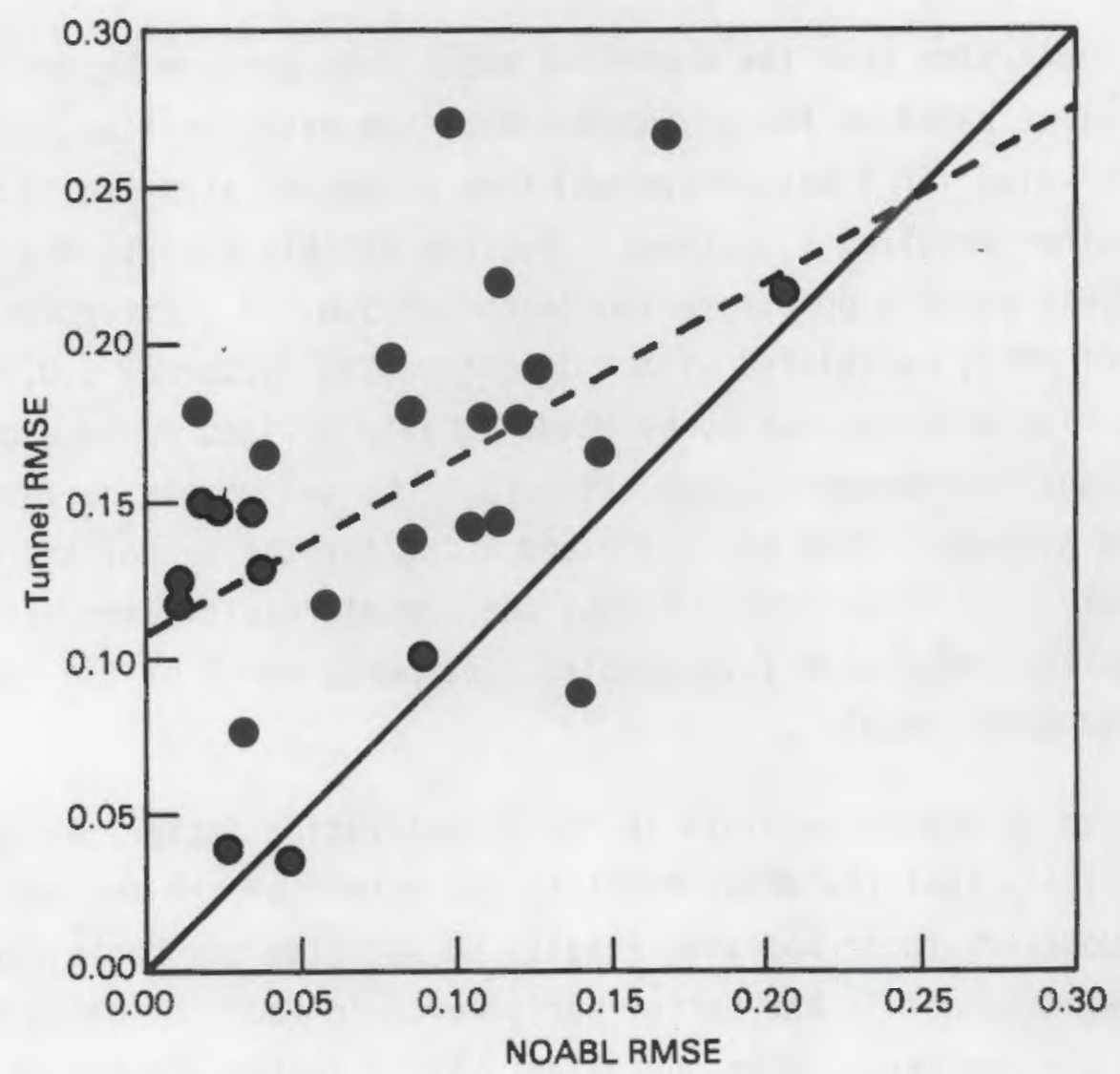

FIGURE 2. Scatterplot of the Tunnel RMSE Versus the NOABL Verification RMSE. The NOABL RMSE was found using a deterioration factor of 1.5. The dashed line is a line of regression fit to these data $\left(r^{2}=0.26\right)$. 
the solid diagonal line. However, in Figure 2 most of the points are above the solid line, indicating that the tunnel did not perform as well as the numerical model for this data set. This inequity in performance is also shown more quantitatively when we compare RMSEs averaged over the 27 cases (obtained simply by summing the individual RMSEs and dividing the sum by 27). The average RMSE for the tunnel is 0.152 . For the NOABL model it is 0.078 , assuming a deterioration factor of 1.5. Thus, if the true deterioration factor is actually close to its assumed value of 1.5 , then the numerical model performs much better than the physical model.

The dashed line in Figure 2 is a line of regression fit to the RMSEs. It illustrates the correlation between the NOABL RMSE and the tunnel RMSE. Although this correlation is not strong $\left(r^{2}=0.26\right)$, a trend is clear--as the numerical model results become worse, so do the wind tunnel results.

The conclusion that the numerical model does perform better than the wind tunnel is based on the assumption that the deterioration factor is about 1.5. This value for $f$ was determined from a limited study so it may not be true for other modeling situations. Because of this uncertainty, we repeated this analysis using a deterioration factor of 3.0. A scatterplot of the 27 pairs of RMSE, calculated with a deterioration factor of 3.0, is shown in Figure 3. The RMSEs appear to be about equally divided above and below the 'line of equal performance' indicating that the two models performed equally well. The averaged RMSEs are 0.152 and 0.156 for the tunnel and NOABL results, respectively. In 14 of the 27 cases, the tunnel results were better than the NOABL results. Thus when $f$ is doubled, the performance of the two techniques seems to be about equal.

Because of the uncertainty in the deterioration factor, we cannot state authoritatively that the NOABL model is the better of the two modeling techniques. However, these modeling results do not give any basis for concluding that the wind tunnel is the better performer. In fact, evidence generally indicates the contrary. When the deterioration factor was set at 1.5 , a value determined from a past study, the numerical model clearly did better. Even when the factor is doubled, the skill of the wind tunnel does not significantly surpass the skill of the NOABL model. Hence, we may reasonably hypothesize that the NOABL simulations of the wind are better than tunnel 
simulations, at least over small areas of complex terrain. Confirmation of this hypothesis will require much more research, using data sets that contain enough wind observation sites so that verification RMSEs can be explicitly calculated.

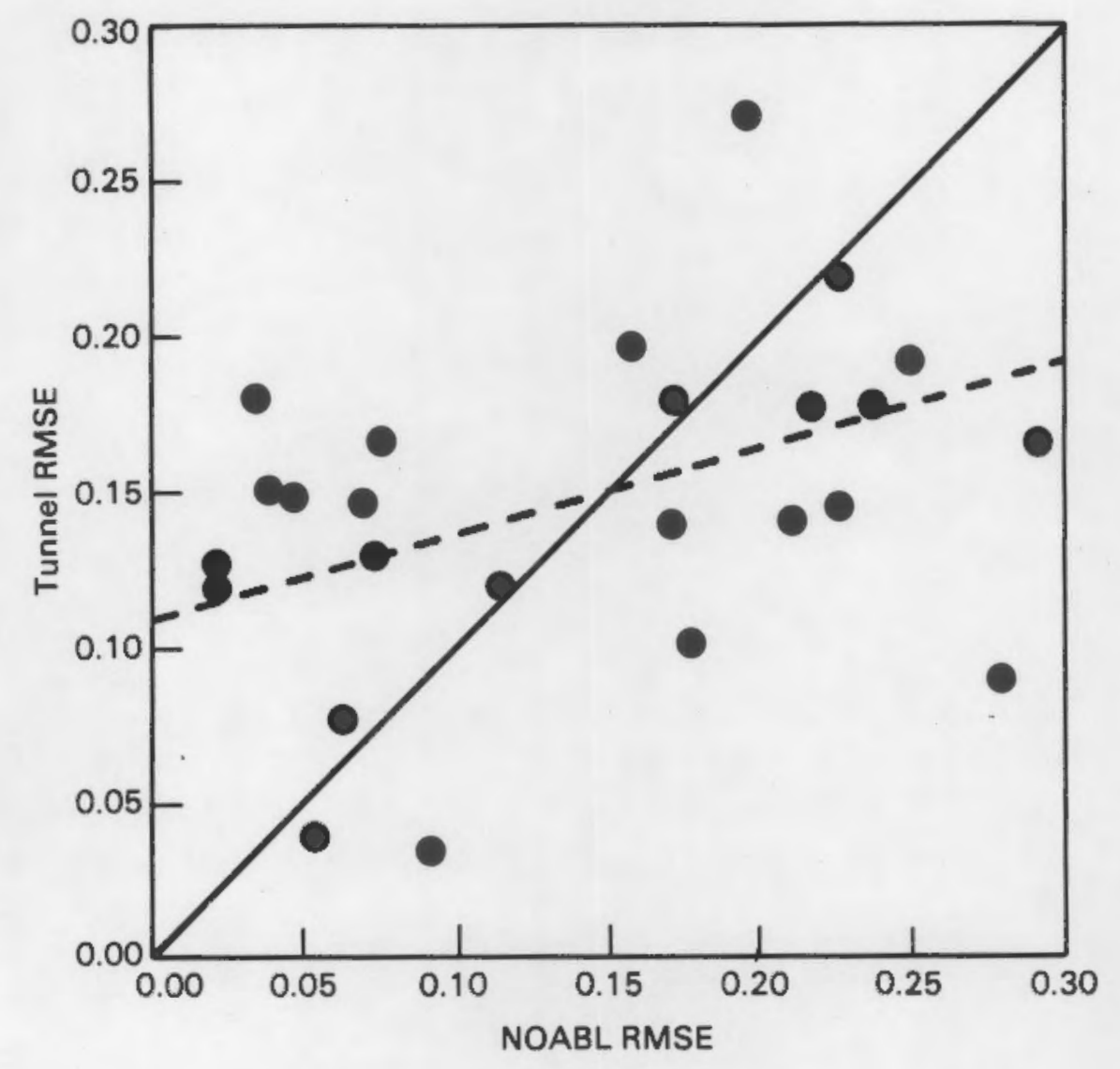

FIGURE 3. Scatterplot of the Tunnel RMSE Versus the NOABL Verification RMSE. The NOABL RMSE was found using a deterioration factor of 3.0. The dashed line is a line of regression fit to these data $\left(r^{2}=0.26\right)$. Two cases lie outside the limits of the graph. These have coordinates $(0.411,0.217),(0.336,0.267)$. 



\subsection{FURTHER EXAMINATION OF THE MODELING RESULTS}

This section is a closer examination of the results from the two modeling techniques. This examination has two goals. First, it is desirable to determine if the optimum stability parameter, $\tau$, and the optimum mean flow direction, $\theta_{0}$, are physically reasonable. Since these are important products of the NOABL model, if they appear to be reasonable, the credibility of these modeling results is improved. Second, the numerical and physical model results are examined together to uncover any clues that could lead to improvements in the wind tunnel results. (Table 4 lists the values of $\tau$ and $\theta_{0}$ calculated by the NOABL mode1.)

In the NOABL model, the stability parameter, $\tau$, governs the relative weight given to wind adjustments in the vertical and horizontal planes. This weighting simulates the effect of atmospheric stability, and although $\tau$ is not a direct measure of the atmospheric stability, as is the Richardson number, $\tau$ should be somewhat related to such measures. If observations of the nearsurface vertical gradients of temperature and wind speed had been made at or near the modeled area, $\tau$ could be compared to Richardson numbers calculated from these observations. Unfortunately, such observations were not made. However, the atmospheric stability near the earth's surface often shows $a^{\prime}$ diurnal pattern, with neutral or slightly unstable conditions during the day followed by more stable conditions at night. Thus, when $\tau$ is plotted versus time of day, a pattern of diurnal variation should appear, provided that the actual stability was also following the expected pattern.

Figure 4 shows optimum $\tau$ values plotted versus time of day for the 27 cases. $\tau$ equals zero represents neutral conditions, $\tau$ greater or less than 0 represents tendencies toward unstable and stable conditions, respectively. Figure 4 illustrates two things about $\tau$ and its relationship to wind tunnel performance. First, $\tau$ does not vary according to the expected diurnal pattern for this set of data. Without actual measurements of the stability, it is not reasonable to conclude that the NOABL model is unable to calculate $\tau$ values that follow the actual stability. The calculated values of $\tau$ may accurately represent the true stability, which in these cases may 
TABLE 4. Mean Flow Direction, $\theta$, and Stability Parameter, $\tau$, as Calculated by the NOABL Model for the 27 Cases

\begin{tabular}{|c|c|c|}
\hline Case & $\theta$ & $\tau$ \\
\hline $1 \mathrm{~B}$ & 195 & -0.70 \\
\hline $2 B$ & 244 & -1.26 \\
\hline 3 & 250 & -0.90 \\
\hline 4 & 174 & 0.14 \\
\hline 5 & 166 & -0.88 \\
\hline $6 \mathrm{~W}$ & 147 & -0.09 \\
\hline $7 W$ & 155 & -0.97 \\
\hline 8 & 153 & -1.61 \\
\hline $9 W$ & 171 & 0.05 \\
\hline 10 & 168 & -0.37 \\
\hline 11 & 253 & -0.57 \\
\hline 12 & 191 & -0.14 \\
\hline 13 & 247 & 0.48 \\
\hline $14 B$ & 223 & 0.12 \\
\hline 15 & 213 & -0.29 \\
\hline 16 & 250 & -0.29 \\
\hline 17 & 255 & -0.81 \\
\hline $18 \mathrm{~B}$ & 187 & -0.84 \\
\hline $19 W$ & 181 & 3.0 \\
\hline 20 & 163 & -1.09 \\
\hline 21 & 237 & -0.17 \\
\hline 22 & 173 & -0.49 \\
\hline 23 & 173 & -1.02 \\
\hline 24 & 177 & 0.43 \\
\hline $25 B$ & 169 & -1.02 \\
\hline 26 & 154 & -1.33 \\
\hline $27 W$ & 161 & 0.05 \\
\hline
\end{tabular}




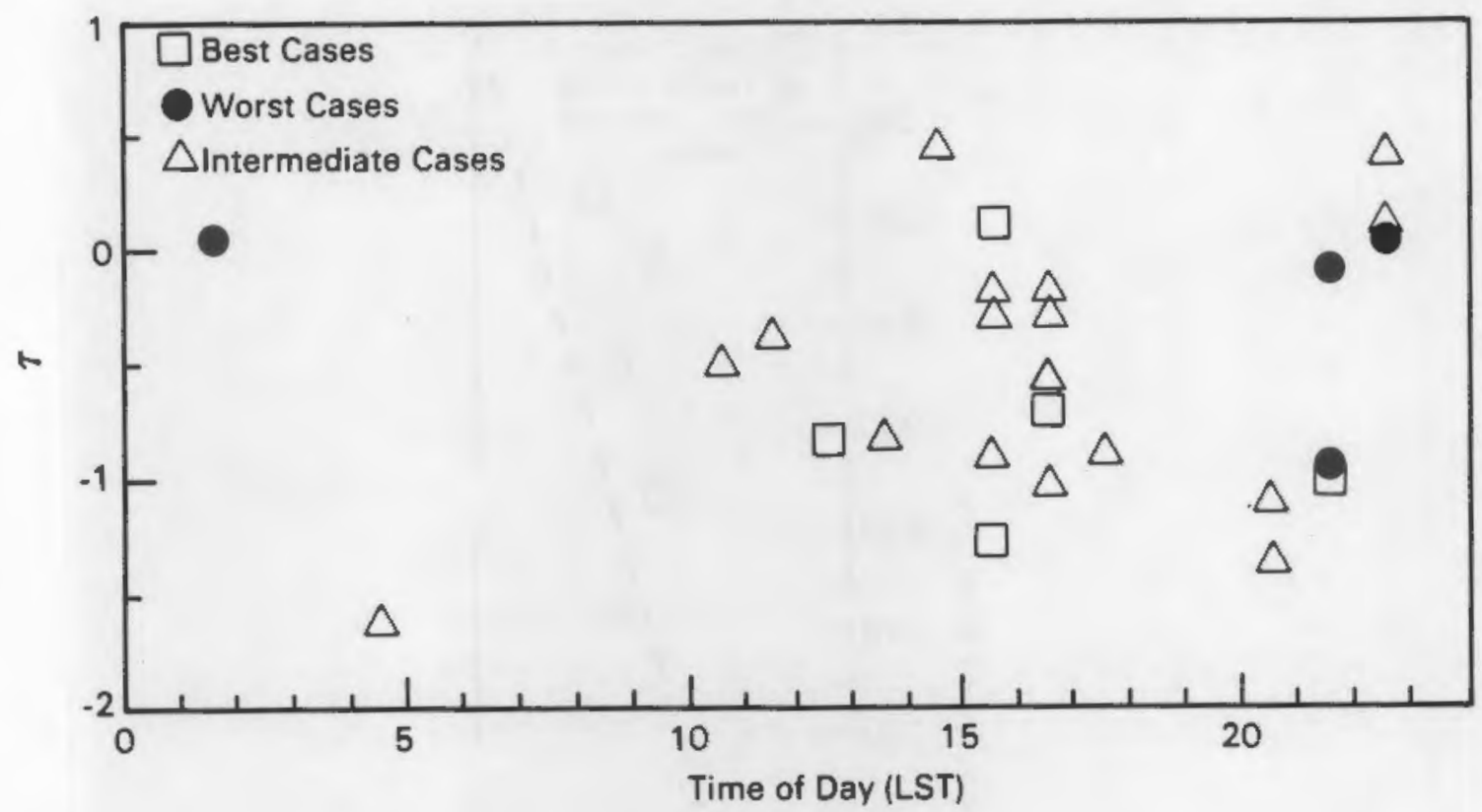

FIGURE 4. The Stability Parameter, $\tau$, as Calculated by the NOABL Model, Plotted Against Time of Day. One of the 'worst cases' did not fall within the limits of the graph. For this case, $\tau=+3$ at zero time of 2200 hours.

not be showing the typical pattern. Second, Figure 4 shows that the $\tau$ values associated with either the good or the poor tunnel cases do not tend to cluster about any specific $\tau$ value. If they had, it might have helped us account for the occurrence of the best and the worst tunnel results.

The optimum wind direction, $\theta_{0}$, that is calculated by the optimizing NOABL model can be thought of as the wind direction that best represents the direction of the mean flow over the wind farm. In Figure $5, \theta_{0}$ is plotted against $\theta_{r}$, the wind direction measured at site 403 . Although this measurement is made near the surface and is undoubtedly influenced to some degree by the local terrain, there should be some correlation between $\theta_{0}$ and $\theta_{r}$. This correlation is evident in figure 5 . (The dashed line is a line of regression fit to these data: $r^{2}=0.56$.)

The correlation between $\theta_{0}$ and $\theta_{r}$ is evidence that $\theta_{0}$ is related to the direction of the actual flow over the wind farm. However, the range over 


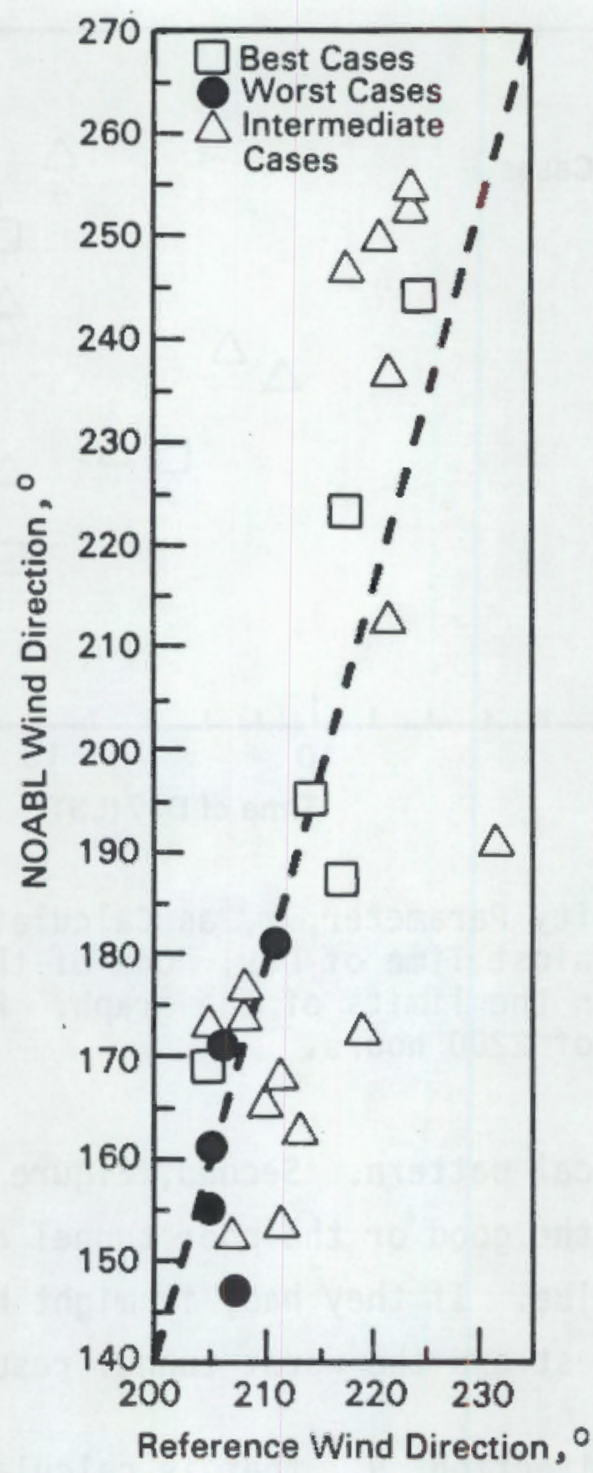

FIGURE 5. The Mean Flow Direction, $\theta_{0}$, as Calculated by the NOABL Model, Plotted Against the Reference Wind Direction, $\theta_{r}$. The dashed line is a line of regression fit to these data $\left(r^{2}=0.56\right)$.

which $\theta_{0}$ varies, from about $145^{\circ}$ to $255^{\circ}$, seems excessive for a climatological point of view. For more than half the cases, $\theta_{0}$ lies between $140^{\circ}$ and $180^{\circ}$. Local flow from these directions may occur, but measurements of wind direction in the area give no evidence that such local flows exist. 
Figure 5 reveals that the worst tunnel cases cluster at the lower values of both $\theta_{0}$ and $\theta_{r}$. The relationship between poor tunnel performance and smaller values of $\theta_{r}$ is illustrated in Figure 6 , which plots the reference wind direction, $\theta_{r}$, against the tunnel RMSE. The dashed line in this figure is a line of regression fit to these data. Although the correlation is not strong $\left(r^{2}=0.13\right)$, the trend is evident: as the reference direction decreases, the tunnel RMSE increases. This relationship is seen much more vividly in Table 5, which gives the average reference directions for the worst, intermediate, and best cases. The average reference direction for the 5 worst cases is about $11^{\circ}$ less than the average direction of the best and intermediate cases. It can then be concluded that poor tunnel cases are associated with more southerly reference wind direction (about $205^{\circ}$ to $210^{\circ}$ ).

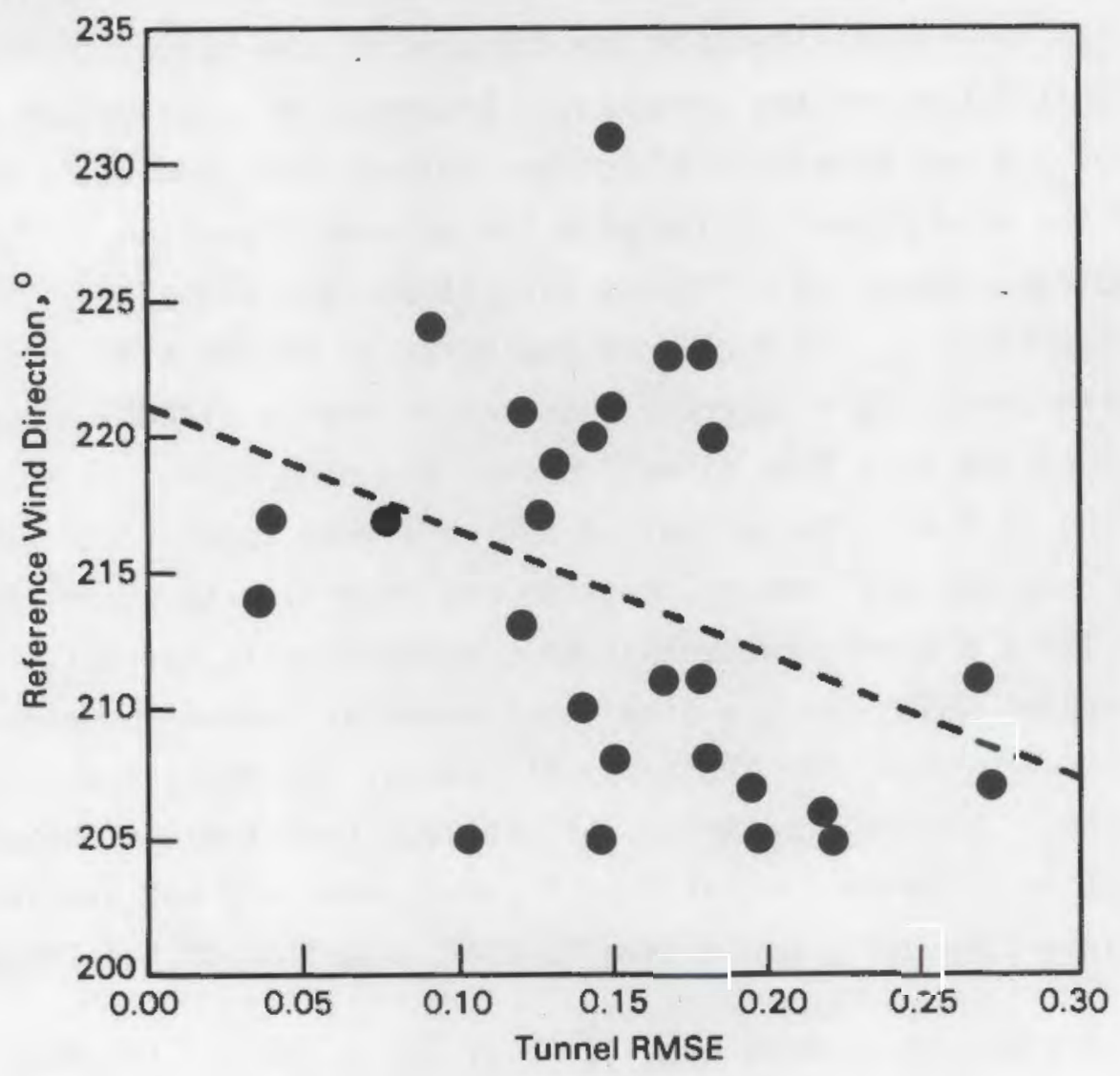

FIGURE 6. The Reference Wind Direction Plotted Against the Wind Tunnel RMSE. The dashed line is a line of regression, $\left(r^{2}=0.13\right)$, that 111 ustrates this trend: as the wind tunnel RMSE increases, the reference direction decreases. 
TABLE 5. Average Reference Direction of the Worst, Intermediate, and Best Tunnel Cases

\begin{tabular}{lrrr}
\multicolumn{2}{c}{ Case } & (Number) & $\begin{array}{c}\text { Average } \\
\text { Reference Direction }\end{array}$ \\
\cline { 1 - 2 } Worst & $(5)$ & 204 \\
Intermediate & $(17)$ & 216 \\
Best & $(5)$ & 215
\end{tabular}

It is important to recall that wind tunnel speed ratios associated with three different assumed wind directions $\left(195^{\circ}, 210^{\circ}\right.$, and $\left.225^{\circ}\right)$ are available for comparison to a specific set of wind observations. Selection of one of these wind tunnel cases is based on the reference direction, $\theta_{r}$, associated with the observations, and wind tunnel ratios whose assumed direction is closest to the reference direction are compared to the observations. The five cases that exhibited the worst match between the observations and the tunnel ratios all had reference directions between $205^{\circ}$ and $211^{\circ}$; these were compared to the wind tunnel ratios with the assumed direction of $210^{\circ}$. Figure 5 indicates that for reference directions less than $210^{\circ}$, the NOABLpredicted direction, $\theta_{0}$, is much more southerly or southeasterly than the reference direction. This suggests that the reference direction may be an overestimate of the true flow direction over the wind farm. If this is the case, then the $195^{\circ}$ wind-tunnel ratios may be a more appropriate representation of the flow than the $210^{\circ}$ ratios, because the true flow is closer to $195^{\circ}$ than $210^{\circ}$. Table 6 demonstrates that this hypothesis is correct. In this table, the tunnel RMSEs for the five worst cases are shown for assumed wind tunnel direction of $210^{\circ}$ and $195^{\circ}$. In all cases, the RMSEs are lower for the $195^{\circ}$ direction. However, the RMSEs for the $195^{\circ}$ tunnel direction are still large, and it is unfortunate that tunnel simulations are not available for directions less than $195^{\circ}$, since even further reduction of the RMSEs may occur.

It is interesting to note that for 5 of the 27 cases, the NOABL-derived direction, $\theta_{0}$, is greater than $230^{\circ}$, and the reference direction, $\theta_{r}$, is greater than $220^{\circ}$. For these cases, one would think that the wind-tunnel ratios associated with an assumed direction of $225^{\circ}$ should provide the closest fit to the observations, because the $225^{\circ}$ simulation is closest to both $\theta_{0}$ 
and $\theta_{r}$. However, for 4 of these cases, the best fit was obtained with the $195^{\circ}$ wind-tunnel ratios, and for the remaining case, the $210^{\circ}$ tunnel ratios gave the best match. Therefore, it seems that both the NOABL-derived wind direction and the reference direction are not reliable guides in selecting which of the three sets of wind-tunnel ratios best represents the actual flow, when $\theta_{0}$ is greater than $230^{\circ}$, and when $\theta_{r}$ is greater than $220^{\circ}$. In this situation, both $\theta_{0}$ and $\theta_{r}$ may overestimate the direction of the actual flow.

TABLE 6. Tunnel RMSE for the Five Worst Cases for Two Assumed Tunnel Directions

\begin{tabular}{|c|c|c|}
\hline \multirow[b]{2}{*}{ Case } & \multicolumn{2}{|c|}{ Wind Tunnel Direction } \\
\hline & $195^{\circ}$ & $210^{\circ}$ \\
\hline 6 & 0.213 & 0.271 \\
\hline 7 & 0.130 & 0.196 \\
\hline 9 & 0.205 & 0.217 \\
\hline 22 & 0.208 & 0.267 \\
\hline 30 & 0.164 & 0.220 \\
\hline
\end{tabular}




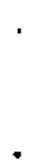




\subsection{CONCLUSIONS AND RECOMMENDATIONS}

The first major goal of this report was to compare the ability of numerical and physical models (i.e., wind tunnel studies) to simulate the winds in complex terrain. This was done by comparing the winds predicted by each technique to wind observations made over the modeled area. Because the wind observation data were limited, it was not possible to conclude, with any sense of authority, which modeling method best simulates the actual wind flow. However, the available evidence does indicate that the numerical model performs better than the wind tunnel. Much more research is necessary to firmly substantiate this finding using data sets that contain many more observation sites.

The second goal of this report was to seek ways to improve the performance of the wind tunnel. This was done by examining the optimum values for the stability parameter, $\tau$, and the optimum mean wind direction, $\theta_{0}$, as calculated by the optimizing NOABL model. The primary purpose of this examination was to see whether certain ranges of these parameters were associated with particularly poor cases of wind tunnel performance. The stability parameter, $\tau$, did not correlate with tunnel performance. On the other hand, poor tunnel results were associated with a certain range in the optimum wind direction, $\theta_{0}$. For the poor cases, $\theta_{0}$ was much less than the reference angle direction, $\theta_{r}$, suggesting the mean flow was actually at a lower wind angle than would be indicated by the reference direction. All the poor tunnel cases assumed a wind tunnel direction of $210^{\circ}$. When the tunnel results for a tunnel direction of $195^{\circ}$ were compared to the observations, the RMSE decreased in all of the 5 cases. This is evidence that the flow was perhaps more from the south or south-southeast than is indicated from the reference direction (at least for reference directions less than $210^{\circ}$ ).

Cases for which the NOABL direction, $\theta_{0}$, was greater than $230^{\circ}$, and the reference direction, $\theta_{r}$, was greater than $220^{\circ}$, did not compare well to the wind-tunnel ratios obtained assuming a direction of $225^{\circ}$. (This is the closest wind-tunnel simulation direction to both $\theta_{0}$ and $\theta_{r}$ ) Thus, the reliability of $\theta_{0}$ and $\theta_{r}$, as a guide in selecting the proper set of wind tunnel ratios, is questionable. 
Evaluation of the numerical modeling simulations would be helped if measurements of the stability and wind direction were made within the modeled area. These measurements would be used to establish if $\tau$ and $\theta_{0}$ are physically realistic. It would be particularly interesting to determine if the south and south-southeasterly flows, as predicted by the model, are actually observed. (The flow direction may be inferred from turbine yaw angles if explicit direction measurements are not made.)

Finally, consideration should be given to applying optimization techniques to the analysis of the wind tunnel simulations. For example, tunnel simulations could be performed at direction increments of $5^{\circ}$ between $160^{\circ}$ and $230^{\circ}$. For each of these simulations, the RMSE between observed and simulated winds could be calculated, and the tunnel simulation with the minimum RMSE would be considered as the best representation of the actual flow. If enough observation sites were available, these could be segregated into tuning sites, used to select one of the tunnel simulations, and verification sites, used to objectively assess the tunnel performance. One could then determine if intelligent selection of one of the tunnel simulations would lead to enhancements in tunnel performance, as gauged by the match between tunnel winds and the actual winds at the verification sites. 


\subsection{REFERENCES}

Barnard, J. C., H. L. Wegley, and T. R. Hiester. 1985. Improving the Performance of Mass-Consistent Models Using Optimization Techniques. PNL-5566, Pacific Northwest Laboratory, Richland, Washington.

Hiester, T. R., and W. T. Penne11. 1981. The Meteorological Aspects of Siting Large Wind Turbines. PNL-2522, Pacific Northwest Laboratory, Richland, washington. 


\section{.}




\section{OISTRIBUT ION}

No. of

Copies

OFFSITE

Carl Aspliden

Battelle Memorial Institute Washington Office

2030 M Street, NW

Washington, DC 20036

J. Cadogan

U.S. Department of Energy

Wind/Ocean Technologies Division

1000 Independence Avenue

Forrestal Building, Room 5H048

Washington, DC 20585

D. F. Ancona

U.S. Department of Energy

Wind/Ocean Technologies Division

1000 Independence Avenue

Forrestal Building, Room 5H048

Washington, DC 20585

G. P. Tennyson

U.S. Department of Energy

Albuquerque 0perations Office

P.0. Box 5400

Albuquerque, NM 87110

H. L. Wegley

17043 154th Place, S.E. Renton, WA 98058
No. of

Copies

\section{ONSITE}

DOE Richland Operations Office

J. J. Sutey/D. R. Segna

37 Pacific Northwest Laboratory

J. C. Barnard (5)

J. W. Buck

J. R. Connell

D. W. Dragnich

C. E. Elderkin

D. L. Elliott

J. M. Hales

$P$. C. Hays

M. E. Hinchee

A. H. Miller

V. R. Morris.

E. L. Owczarski

D. C. Powe ll

J. A. Stottlemyre

T. K. Thompson

L. L. Wendel1 (10)

R. E. Wildung

Publishing Coordination (2)

Technical Information (5) 
